\title{
Reasons and Solutions for the Insufficient Peasantry Financial Demand in Shandong Province of China
}

\author{
Shujuan Ding ${ }^{1}$ \\ ${ }^{1}$ Economic School, Shandong Normal University, China \\ Correspondence: Shujuan Ding, Economic School, Shandong Normal University, No. 88, Wenhuadong Road, \\ Jinan, Shandong Province, P. R. China. Email: shujuanding@sina.com
}

Received: September 5, 2014

Accepted: September 22, 2014

Online Published: September 25, 2014

doi:10.5539/ijbm.v9n10p195

URL: http://dx.doi.org/10.5539/ijbm.v9n10p195

\begin{abstract}
In order to know the real situation of the peasants' financial demand in Shandong province, questionnaire survey method is accepted. According to the 8537 questionnaires, using the descriptive analysis, the peasants' financing demand in Shandong rural area is insufficient. According to this investigation, unfamiliarity with finance, departure of main labor force and the small-size intensive and scale management are the main reasons. In order to increase the financial demand, it is necessary for government to enlarge propaganda through $\mathrm{TV}$, and financial institutions to build more branches beforehand. Besides, the transfer of land, scientific training and more support to agriculture are also needed.
\end{abstract}

Keywords: rural area, Shandong, peasantry financial demand

\section{Introduction}

"Inclusive finance" is put forward in 2005 by the United Nations. According to CGAP, for a financial system to be truly inclusive, it should meet the needs of everyone who can fruitfully use financial services, including the poor. Poor people in developing countries, like everyone else, need access to a wide range of financial services that are convenient, flexible, and reasonably priced. To help poor people with financing are the main objective of inclusive finance. According to Goldsmith(1969), Mchinnon (1973), Banerjee and Newman (1993), Galor and Zeira (1993), Stiglitz (1994), World Bank (2001), Robinson \& Marguerite (2001), He WenGuang \& Li Lili (2005), Demirguc-Kunt and Levine (2007), proper financing is an effective way to help the poor people to get out of poverty. In China, the peasants' income is relatively low, and they are the main objects of inclusive finance service. China entered Alliance for Financial Inclusion in September 2011. In 2013, "Decision of the Central Committee of the Communist Party of China of Some Major Issues Concerning Comprehensively Deepening the Reform" points out that "to develop inclusive finance is an important part to improve and perfect the financial market". Therefore, China's inclusive finance and especially rural finance has been an important area that obtains much attraction. There are many ways to develop rural finance. Whether or not to be able to choose the best way depends on the thorough understanding of the reality. Many institutions and scholars (Research Center of Rural Economy of Department of Agriculture in 2004, the People's Bank of China in 2006, Pin Xinqiao (2007, 2008) and Pan (2013) have carried out surveys on rural areas trying to know the reality. But the survey of the People's Bank of China and that of Pin Xinqiao did not include Shandong Province. The survey of Research Center of Rural Economy of Department of Agriculture touched Shandong province very slightly. The survey of Pan only investigated one county in Shandong Province. So most of these investigations didn't touch Shandong rural area or the surveys that touch Shandong are too simple and can not reflect the whole financing situation of Shandong rural area. Therefore, in January 2014, we carried out a large-scale survey supported by China's Inclusive Finance Center (CIFC) to investigate the whole Shandong province more thoroughly.

\section{Methodology}

Generally speaking, questionnaire investigation method is adopted to figure out the main outline of the rural financial demand. From January to March, 2014, we launched an investigation all over Shandong rural areas. 10150 questionnaires are handed out and 8537 effect questionnaires are taken back. The investigation object is peasants in Shandong province. In every village, 35 peasants are selected randomly. 1-4 counties are selected for each prefecture-level city. The 17 prefecture-level cities in Shandong province are all included in the investigation. And 242 counties are investigated. More than 200 university students took part in the investigation. 
The villages invested are the hometown of the students taken part in this investigation, which can dispel the misgiving from the peasants and can ascertain the correction of the investigation. According to investigation, descriptive analysis is used to analyze the current situation of the financial demand, the reasons of the current situation and the ways to solve the problems.

\section{Current Situation of Low Peasantry Financial Demand in Shandong}

According to this survey, $76.14 \%$ peasants express they need not financing and only $23.86 \%$ peasants say they need financing. There is no much differences among the 17 prefecture-level cities. (see Table 1).

Table 1. Distribution of whether need financing or not for peasants in Shandong province (\%)

\begin{tabular}{ccc}
\hline Areas & No need of financing & Need of financing \\
\hline Shandong Province & 76.14 & 23.86 \\
Jinan & 72.43 & 27.57 \\
Qingdao & 80.41 & 19.59 \\
Zibo & 76.25 & 23.75 \\
Zaozhuang & 69.31 & 30.69 \\
Dongying & 65.7 & 34.3 \\
Yantai & 79.72 & 20.28 \\
Weifang & 78.94 & 21.06 \\
Jining & 77.81 & 22.19 \\
Tai'an & 76.26 & 23.74 \\
Weihai & 87.94 & 12.06 \\
Rizhao & 78.66 & 21.34 \\
Laiwu & 71.86 & 28.14 \\
Linyi & 79.13 & 20.87 \\
Dezhou & 70.65 & 29.35 \\
Liaocheng & 70.39 & 29.61 \\
Binzhou & 77.19 & 22.81 \\
Heze & 74.11 & 25.89
\end{tabular}

Note. Shandong Province includes 17 prefecture-level cities which are Jinan, Qindao, Zibo, Zaozhuang, Dongying, Yantai, Weifang, Jining, Tai'an, Weihai, Rizhao, Laiwu, Linyi, Dezhou, Liaocheng, Binzhou, Heze.

Resourse: Survey of China's Inclusive Finance Center.

Although we don't have the data for the whole countries' peasants financing will, we still can confer safely that the financing will of peasants' in Shandong is lower than that of the whole country. The conclusion was made according to the flowing two facts. The first is that in 2006, the People's Bank of China carried out a survey to 20040 peasants in 10 provinces without Shandong. According to that survey, there are $46.86 \%$ peasants who wanted credit, which is higher than the $23.86 \%$ in Shandong 8 years later. During the 8 years, inclusive finance has been prompted heavily in China. In 2006, China Banking Regulatory Commission broadened the entry criterion for banks to enter rural market. Since then, policies that push forward the development of rural financial market appeared constantly. For example, in August 2007, April 2008, China Banking Regulatory Commission demanded that the entry criterion for banks to enter rural market be broaden further, and the new-pattern rural financial institution be developed faster; On October 14, 2008, the Third Plenary Session of the Seventeenth Central Committee of the Communist Party of China paid more attention to rural problems and demanded that "modern rural financial system" should be set up; In 2010, China Banking Regulatory Commission promulgated note to promote the development of new-pattern rural financial institutions. In the efforts of government and kinds of financial institutions, financial services have been raised to a higher level. But after 8 years, the percentage of peasants with financial demands in all of the peasants in Shandong's is only $23.86 \%$, which is obviously lower than the level of that in all over the country. The second fact is that the average net rural per capita income of all the country is RMB8896 in 2013 according to National Bureau of Statistics, while that of Shandong Province is RMB10620, which is much higher. According to the traditional financial theory, the higher the economic development level, the more the financial demand. But the financial demand is not accordance with the economic position for Shandong Province. 


\section{Reasons and Solutions for Peasants' Insufficient Financial Demand in Shandong}

\subsection{Financial Propagation Is not Sufficient}

During the investigation, we find a prominent problem is that many peasants have no knowledge of some financial products and institutions, especially internet finance and some insurance products. Shandong persons are very conservative and the will to take risk is less than persons from other provinces, for example Zhejiang Province, Guangdong Province and so on. One kind of manifestation is they will not do something except they have some knowledge of it. Therefore, in order to develop inclusive finance, kinds of inclusive finance service and institutions must be known by Shandong's peasants. According to our investigation, Shandong province has a good education situation, more than $90 \%$ peasants receive junior middle school or higher level education (see table 2). Good education basis will insure the good effect of sufficient propagation.

Table 2. Distribution of education degree $(\%)$

\begin{tabular}{ccccccccc}
\hline Areas & $\begin{array}{c}\text { not } \\
\text { educated }\end{array}$ & $\begin{array}{c}\text { primary } \\
\text { school }\end{array}$ & $\begin{array}{c}\text { junior } \\
\text { middle } \\
\text { school }\end{array}$ & $\begin{array}{c}\text { senior } \\
\text { middle } \\
\text { school }\end{array}$ & $\begin{array}{c}\text { technical } \\
\text { secondary } \\
\text { school }\end{array}$ & $\begin{array}{c}\text { junior } \\
\text { college }\end{array}$ & $\begin{array}{c}\text { bachelor } \\
\text { degree }\end{array}$ & $\begin{array}{c}\text { master degree } \\
\text { and higher }\end{array}$ \\
\hline Shandong & 0.66 & 5.45 & 31.95 & 21.21 & 8.71 & 12.24 & 18.53 & 1.25 \\
Province & & & & & & & \\
Jinan & 0.15 & 4.22 & 24.28 & 20.81 & 11.01 & 14.33 & 22.32 & 2.87 \\
Qingdao & 0.44 & 2.64 & 26.54 & 20.09 & 11.29 & 13.78 & 21.99 & 3.23 \\
Zibo & 0.35 & 5.81 & 36.27 & 22.18 & 7.04 & 10.21 & 17.43 & 0.7 \\
Zaozhuang & 0.36 & 5.36 & 28.57 & 23.57 & 8.21 & 11.79 & 21.07 & 1.07 \\
Dongying & 0 & 2.86 & 21.43 & 15.71 & 8.57 & 26.07 & 25 & 0.36 \\
Yantai & 0 & 3.72 & 27.71 & 23.53 & 11.92 & 16.87 & 15.63 & 0.62 \\
Weifang & 0.84 & 2.86 & 29.24 & 25.78 & 8 & 10.26 & 21.96 & 1.07 \\
Jining & 0.8 & 4.82 & 35.96 & 23.11 & 9.95 & 10.91 & 13.64 & 0.8 \\
Tai'an & 0.36 & 4.64 & 30.71 & 17.14 & 13.93 & 11.79 & 20.71 & 0.71 \\
Weihai & 0.63 & 6.67 & 35.87 & 22.22 & 15.56 & 9.84 & 7.94 & 1.27 \\
Rizhao & 1.59 & 6.67 & 20 & 16.19 & 9.84 & 18.41 & 26.67 & 0.63 \\
Laiwu & 0 & 6.4 & 17.73 & 31.03 & 15.76 & 14.78 & 12.81 & 1.48 \\
Linyi & 0.41 & 7.49 & 47.68 & 17.85 & 5.99 & 6.54 & 13.49 & 0.54 \\
Dezhou & 2.21 & 9.35 & 36.9 & 16.33 & 5.27 & 8.33 & 20.75 & 0.85 \\
Liaocheng & 0.36 & 8.42 & 29.93 & 27.06 & 4.12 & 12.54 & 16.67 & 0.9 \\
Binzhou & 1.83 & 9.48 & 48.01 & 13.46 & 4.89 & 6.73 & 14.98 & 0.61 \\
Heze & 0.84 & 4.87 & 32.44 & 21.18 & 5.04 & 13.61 & 20.67 & 1.34 \\
\hline Rer & & & & & &
\end{tabular}

Resourse: Survey of China's Inclusive Finance Center.

Then how to make the peasants familiar with kinds of financial services and institutions? The first way is the official popularization of financial knowledge throw TV program. According to our survey, TV program is the most important way to obtain financial knowledge (which is more important than internet, newspaper, books, communication with friends and relatives). Therefore it will be more effective to propagate financial knowledge through TV program. The government's or official propagation will be more effective because peasants' psychological conflict will be small. The second way is to build up more branches or sub-branches of financial institutions. According to Huge T. Patrick (1996), the way to develop rural finance is different for developed and undeveloped region. In developed area, the strategy should be "following demand", while in undeveloped area, "supply leading" strategy should be adopted. When the financing demand is insufficient in rural areas, financial institutions may built branches first and foster the market. When the branches are built not far from where the peasants lived, the peasants will get to know it naturally and therefore financial demand may occur.

\subsection{Departure of Rural Labor Force Is Serious}

According to table 3, among the income resources, wages income is the most important. The second important is agriculture income and the third important is non-agriculture self-employment income. Therefore, peasants workers going out occupied an important percentage, the workforces still staying in rural areas mainly deal with traditional agriculture and seldom with non-agriculture self-employment business. An important part of the labor force leave the rural area and become working peasants in urban area. The main reason for their departure is that 
in rural area, the profit work chances are relatively less than in cities. In rural area, the main production model is still traditional agriculture model. As the lands can contracted for every peasants are less and less, and even none in some villages as the urbanization is going on and population in rural area is becoming larger, many peasants, especially young peasants, feel that it is too difficult to earn enough money depending on these limited lands, especially by the traditional agriculture production model. So many of the young people go out. And the left are mainly children and old persons. This circumstance may explain partly the reason for insufficient financing. The main labor forces leave rural area to work outside and an important portion of the left are elder persons and children whose financial demand is little, another important portion of the left engaged in traditional farming and their financial demand is also not much. Therefore the financial demand in Shandong rural area is not sufficient.

Then how to attract and keep the main labor force in rural area? To foster new-type rural management subjects which is often connected intensive and scale management is an important way. Through this way, the labor force in rural area can obtain higher income, and at the same time, the problem of "nobody do faming" can be solved. But in the rural area of Shandong province, the new -type rural management subjects are rare which is connected with intensive and scale management.

Table 3. Average importance of income sources

\begin{tabular}{lllll}
\hline Areas & Agriculture Income & Non-Agriculture Self-employment Income & Wages Income & Other Income \\
\hline Shandong Province & 3.955 & 2.868 & 4.125 & 2.041 \\
Jinan & 3.779 & 3.082 & 3.854 & 2.850 \\
Qingdao & 3.764 & 3.245 & 5.421 & 2.136 \\
Zibo & 3.248 & 2.975 & 4.788 & 1.846 \\
Zaozhuang & 3.896 & 2.756 & 4.050 & 1.701 \\
Dongying & 3.476 & 2.960 & 4.276 & 2.372 \\
Yantai & 3.943 & 2.625 & 4.129 & 1.825 \\
Weifang & 3.976 & 3.011 & 4.068 & 1.969 \\
Jining & 4.093 & 2.720 & 4.152 & 2.598 \\
Tai'an & 4.085 & 3.153 & 3.502 & 1.864 \\
Weihai & 3.797 & 2.310 & 4.116 & 1.350 \\
Rizhao & 4.088 & 3.412 & 4.251 & 2.168 \\
Laiwu & 3.621 & 2.675 & 3.995 & 2.580 \\
Linyi & 4.142 & 3.157 & 3.756 & 1.768 \\
Dezhou & 4.528 & 2.428 & 3.754 & 2.027 \\
Liaocheng & 3.769 & 2.757 & 3.935 & 1.716 \\
Binzhou & 4.204 & 2.398 & 3.583 & 2.248 \\
Heze & 4.498 & 2.767 & 4.118 & 1.682 \\
\hline
\end{tabular}

Note. 1-7 are used to represent the importance level. 1: the most unimportant. 7: the most important;

Resourse: Survey of China's Inclusive Finance Center.

\subsection{Proportion of Intensive and Scale Management Is Small}

According to our investigation (table 4), most of the peasants in Shandong province are not belong to new-type rural management subjects. New-type rural management subjects are those agricultural management organizations whose management scale is large, intensive degree is high and market competitiveness is strong, and those professional peasant who are well-educated, understand the technology and good at management under household contract responsibility system. New-type rural management subjects include family farm or professional large family, union operation, farmer cooperatives, corporate champion and so on. "Family farm" is an agriculture body that engaged in intensive, scale and commercialized management using the family members as workers. And the income from agriculture is the main income resource. "Farmer cooperatives" is such a production mode under which several peasants families are united together. In this mode, the land can become large, and the work forces are more and scale management is possible. "Corporate champion" refers to an enterprise that can exploit the market, can carry on agricultural products deep processing, provide a series of services to peasants and lead thousands of peasants into market. The objective of new-type rural management subjects is no longer self-sufficiency and satisfying their own life demands, but to earn profit and belong to productive objectives. At the same time, new-type rural management subjects need advanced technology to take 
on large scale production. Their investments are usually large and the possibility for them to have considerable income is also large. Therefore new-type rural management subjects may have financing demand and also have the ability to repay. They will be the main body of financing demander. But from this investigation, more than $80 \%$ peasants are not new-type rural management subjects, but self-sufficient satisfying-live-demand management bodies. And this is one reason for the insufficient financial demand.

Table 4. Distribution of new-type rural management subjects (\%)

\begin{tabular}{lcccccc}
\hline \multicolumn{1}{c}{ Areas } & $\begin{array}{c}\text { Family Farm or Professional } \\
\text { Large Family }\end{array}$ & $\begin{array}{c}\text { Union } \\
\text { Operation }\end{array}$ & $\begin{array}{c}\text { Farmer } \\
\text { Cooperatives }\end{array}$ & $\begin{array}{c}\text { Corporate } \\
\text { Champion }\end{array}$ & $\begin{array}{c}\text { Other } \\
\text { Not Belong } \\
\text { to }\end{array}$ \\
\hline Shandong & 4.76 & 1.64 & 4.93 & 1.11 & 6.68 & 80.86 \\
Province & 4.7 & 1.06 & 5 & 1.82 & 7.58 & 79.85 \\
Jinan & 1.62 & 0.59 & 1.18 & 0 & 1.33 & 95.28 \\
Qingdao & 4.77 & 0.35 & 3.89 & 0.18 & 2.12 & 88.69 \\
Zibo & 2.17 & 0.36 & 14.8 & 8.66 & 3.25 & 70.76 \\
Zaozhuang & 9.39 & 4.69 & 10.11 & 6.14 & 7.22 & 62.45 \\
Dongying & 8.99 & 1.09 & 5.27 & 0.16 & 8.53 & 75.97 \\
Yantai & 5.88 & 2.04 & 5.76 & 0.72 & 8.99 & 76.62 \\
Weifang & 3.1 & 7.03 & 6.86 & 0.33 & 9.64 & 73.04 \\
Jining & 2.86 & 1.07 & 4.64 & 2.14 & 9.29 & 80 \\
Tai'an & 0 & 0.32 & 0.63 & 0.63 & 1.9 & 96.51 \\
Weihai & 9.97 & 0.96 & 12.22 & 0 & 4.5 & 72.03 \\
Rizhao & 12.38 & 3.96 & 7.92 & 3.96 & 10.89 & 60.89 \\
Laiwu & 5.63 & 0.7 & 2.25 & 0 & 8.86 & 82.56 \\
Linyi & 5.48 & 1.71 & 2.4 & 1.54 & 3.77 & 85.1 \\
Dezhou & 3.25 & 0.36 & 0.72 & 0 & 3.44 & 92.22 \\
Liaocheng & 1.83 & 0.31 & 8.26 & 0.31 & 8.56 & 80.73 \\
Binzhou & 2.37 & 1.69 & 4.92 & 0.68 & 12.37 & 77.97 \\
Heze & & & & &
\end{tabular}

Resourse: Survey of China's Inclusive Finance Center.

Then how to accelerate the intensive and large-scale management? Firstly, the land-use right must be able to be transferred, which is the precondition for large-scale management. Besides, only the land-use right is able to be transferred, the land-use right can be treated as collateral goods. The transfer of land-use right must obtain the support from the government or the current law. Secondly, peasant's scientific training is needed. The objective of intensive and large-scale management is modern agriculture, which needs the support of science and technology. Thirdly, support from the government and kinds of security are needed for the agricultures development. Agriculture is weak industry. The investment period is long and the risk is high, which need the improvement of insurance and suitable government subsidy to even the fluctuation, reduce the risk and attract more peasants to join in New-type rural management subjects.

\section{Conclusions}

The financial demand in Shandong rural area is relatively less than that of the whole country. According to traditional financial theories, proper financial supply can give impetus to economy. But if the financing demand is insufficient, finance can not exert its influence on economy. Therefore, financing demand is needed to be stimulated. Several ways may be effective. The first is to strengthen the propaganda of finance knowledge and encourage the institutions to built up more branches which may make the peasants more familiar with kind of financial products. The second is to develop intensive and scale management more to attract main labor force to stay in rural area and also make the new-type rural management subjects have the ability to repay the principal and the interest.

\section{Acknowledgement}

Supported by Inclusive finance survey in Shandong Province (00103) from China's Inclusive Finance Research Center. 


\section{References}

Banerjee, A. V., Newman, A. F. (1993). Occupational choice and the process of development. Journal of Political Economy, 101(2), 274-298. http://dx.doi.org/10.1086/261876

CGAP. (2006). Access for All: Building Inclusive Financial Systems. Washington, DC: World Bank.

Dong, Z. Y. (2011). Statistics on China's rural credit situation. Research on Economics and Management, 1, 2-6.

Goldsmith, R. (1969). Finance Structure and economic development. New Haven: Yale University Press.

He, W. G., Li, L. L. (2005). Operation mechanism efficiency appraisal of micro finance from formal finance. Beijing: Economic Science Press.

Machinnon, R. (1973). Money and Capital in Economic in Development. Washington, DC: Brooking Institution.

Oded, G., Joseph, Z. (1993). Income Distribution and Macroeconomics. Review of Economic Studies, 60(1), 35-52. http://dx.doi.org/10.2307/2297811

Pan, S. M., Chen, J. X., \& Liu, W. J. (2013). Deand and differences of basic financial services. Rural Finance, 5 , $100-102$.

People's Bank of China. (2009). Report on the survey of peasants' borrow and lending. Bejing: Economic Science Press.

Robinson, M. (2001). The microfinance revolution: sustainable finance for the poor. Washington D.C.: The World Bank and Open Society Institute. http://dx.doi.org/10.1596/0-8213-4524-9

Thorsten, B., Asli, D. K., \& Ross, L. (2007). Finance, inequality and the poor. Journal of Economic Growth, 12(1), 27-49. http://dx.doi.org/10.1007/s10887-007-9010-6

United Nations. (2006). Building Inclusive Financial Sectors for Development. Department of Economic and Social Affairs \& United Nations Capital Development Fund.

Zhou, X. C. (2013). Fufill party's mass line, push on the development of inclusive finance. Qiushi, 9, 11-17.

\section{Copyrights}

Copyright for this article is retained by the author(s), with first publication rights granted to the journal.

This is an open-access article distributed under the terms and conditions of the Creative Commons Attribution license (http://creativecommons.org/licenses/by/3.0/). 